\title{
PKM Promkes Kelompok Masyarakat Tentang Adaptasi Kebiasaan Baru di Masa Pandemi COVID-19 di Kelurahan Bangetayu Wetan
}

\author{
Endang Supriyanti ${ }^{1}$, Dyah Restuning Prihati ${ }^{1}$, Maulidta Karunianingtyas Wirawati ${ }^{1}$ \\ ${ }^{1}$ Prodi DIII Keperawatan Universitas Widya Husada Semarang \\ e-Mail: lithafikha@gmail.com, dyah.erpe@gmail.com, maulidtakw@gmail.com
}

\begin{abstract}
ABSTRAK
Adaptasi kebiasaan baru adalah tindakan atau perilaku yang dilakukan oleh masyarakat dan semua institusi yang ada di wilayah tersebut untuk melakukan pola harian atau pola kerja atau pola hidup baru yang berbeda dengan sebelumnya. Salah satu upaya untuk mewujudkan penerapan adaptasi kebiasaan baru oleh semua masyarakat adalah dengan sosialisasi yaitu memberikan pendidikan kesehatan. Pendidikan kesehatan merupakan upaya untuk meningkatkan kemampuan masyarakat dalam memelihara dan meningkatkan kesehatannya. Masyarakat kelurahan Bangetayu Wetan belum tahu tentang arti dari adapatasi kebiasaan baru karena belum pernah mendapatkan pendidikan kesehatan tentang perilaku adaptasi kebiasaan baru. Kelurahan Bangetayu Wetan terletak sekitar 18 KM dari Universitas Widya Husada Semarang, merupakan kelurahan dengan kasus konfirmasi positif COVID19 cukup tinggi. Sebagian besar masyarakat tidak patuh memakai masker pada saat keluar rumah dan beranggapan bahwa new normal adalah kembali hidup normal seperti sebelum terjadi pandemi covid-19. Tujuan dari pelaksanaan PKM ini adalah upaya peningkatan pengetahuan dan mengembangkan perilaku sehat untuk mencegah penularan COVID -19 khususnya di wilayah RT 11 RW 02 Bangetayu Wetan. Setelah dilakukan kegiatan PKM ini terjadi peningkatan pengetahuan dan perubahan perilaku masyarakat RT 11 RW 02 Bangetayu Wetan khususnya memakai masker dan mencuci tangan. Akan tetapi perubahan perilaku belum optimal karena masyarakat beranggapan wilayahnya masih aman dari COVID-19.
\end{abstract}

Kata kunci: promkes, adaptasi kebiasaan baru, COVID -19

\begin{abstract}
The adaptation of new habits is an action or behavior carried out by the community and all existing institutions in the region to carry out daily patterns or work patterns or new patterns of life that are different from before. One of the efforts to realize the application of adaptation to new habits by all people is by socialization, namely providing health education. Health education is an effort to improve people's ability to maintain and improve their health. The people of Bangetayu Wetan village do not know the meaning of new habit adaptation because they have never received health education about adapting new habits. Bangetayu Wetan Village, located about $18 \mathrm{KM}$ from Widya Husada University Semarang, is a sub-district with quite high positive cases of COVID-19. Most people do not comply with wearing masks when they leave the house and think that new normal is a return to normal life as it was before the Covid-19 pandemic. The purpose of implementing this PKM is to increase knowledge and develop healthy behaviors to prevent transmission of COVID -19, especially in the RT 11 RW 02 Bangetayu Wetan area. After this PKM activity was carried out, there was an increase in knowledge and a change in the behavior of the people of RT 11 RW 02 Bangetayu Wetan, especially wearing masks and washing hands. However, behavior change has not been optimal because people think the area is still safe from COVID-19
\end{abstract}

Keywords: health promotion, adaptation to new habits , COVID -19 


\section{PENDAHULUAN}

Badan Kesehatan Dunia (WHO) telah menyatakan Corona Virus Disease 2019 (COVID-19) sebagai sebuah pandemi. Penyebaran COVID-19 di Indonesia saat ini sudah semakin meluas lintas wilayah dan lintas negara yang diiringi dengan peningkatan jumlah kasus dan/atau jumlah kematian. Situasi ini kian berdampak pada aspek politik, ekonomi, sosial, budaya, pertahanan, dan keamanan, serta kesejahteraan masyarakat di Indonesia, sehingga diperlukan strategi dan upaya yang komprehensif dalam percepatan penanganan COVID-19. WHO sudah menyampaikan bahwa virus COVID-19 tidak bisa hilang dalam waktu singkat dan menjadi masalah di seluruh dunia. Oleh karena itu tatanan hidup normal yang baru perlu diterapkan oleh masyarakat. (Kemkes, 2020).

Pada masa pandemi masyarakat Indonesia diharuskan hidup dengan tatanan hidup baru, yang dapat 'berdamai' dengan COVID-19. Adapun yang dimaksud dengan adaptasi kebiasaan baru adalah suatu tindakan atau perilaku yang dilakukan oleh masyarakat dan semua institusi yang ada di wilayah tersebut untuk melakukan pola harian atau pola kerja atau pola hidup baru yang berbeda dengan sebelumnya agar masyarakat tetap produktif dan aman dari COVID -19 di masa pandemi. Maksud dari Adaptasi Kebiasaan Baru adalah agar kita bisa bekerja, belajar dan beraktivitas dengan produktif di era Pandemi COVID -19 (Irawati, 2020).

Dalam tatanan kehidupan normal yang baru tidak berarti membatasi produktivitas setiap orang. Masyarakat harus tetap produktif dengan memperhatikan protokol kesehatan dalam pencegahan penularan COVID -19 (Kemkes, 2020). Kita dituntut untuk mampu mengadaptasi/ menyesuaikan kebiasaan baru dimanapun kita berada, seperti di rumah, di kantor, di sekolah, di tempat ibadah, dan juga di tempat-tempat umum, seperti terminal, pasar, dan mal. Diharapkan dengan seringnya menerapkan kebiasaan baru dimanapun, semakin mudah dan cepat menjadi norma individu dan norma masyarakat. Dengan demikian, kita bisa bekerja, belajar, beribadah dan beraktivitas lainnya dengan aman, sehat dan produktif. Adaptasi kebiasaan baru yang dimaksud adalah: sering cuci tangan pakai sabun, pakai masker, jaga jarak, istirahat cukup dan rajin olahraga, serta makan makanan bergizi seimbang (Irawati, 2020).

Basis perubahan adaptasi kebiasaan baru ada pada keluarga. Oleh karena itu keluarga harus bisa memberikan teladan agar bisa menerapkan kehidupan normal yang baru (Kemkes, 2020). Supaya keluarga mampu menerapkan adaptasi kebiasaan baru membutuhkan pengetahuan dan pemahaman tentang adaptasi kebiasaan baru. Salah satu upaya untuk meningkatkan pengetahuan dan pemahaman tersebutadalah dengan memberikan pendidikan kesehatan.

Pendidikan kesehatan merupakan proses meningkatkan kemampuan masyarakat dalam memelihara dan meningkatkan kesehatannya, untuk mencapai derajat kesehatan yang sempurna, baik fisik, mental dan social. Oleh karena itu masyarakat harus mampu mengenal dan mewujudkan aspirasinya, kebutuhannya, serta mampu mengubah atau mengatasi lingkungannya (lingkungan fisik, sosial, budaya, dan sebagainya). Tujuan pendidikan kesehatan yaitu untuk memperoleh pengetahuan dan pemahaman pentingnya kesehatan guna tercapainya perilaku kesehatan dalam upaya meningkatkan derajat kesehatan fisik, mental dan sosial, sehingga produktif secara ekonomi maupun social. Pendidikan kesehatan juga bertujuan untuk meningkatkan derajat kesehatan masyarakat baik jasmaniah maupun rohaniah melalui pemahaman dan pengalaman gaya hidup sehat bagi masyarakat (Bensley, 2008). Melalui pendidikan kesehatan diharapkan pengetahuan masyarakat tentang adapatasi kebiasaan baru menjadi meningkat khususnya masyarakat kelurahan Bangetayu Wetan.

Kelurahan Bangetayu Wetan kecamatan Genuk, Kota Semarang, Provinsi Jawa Tengah terletak sekitar $18 \mathrm{KM}$ dari Universitas Widya Husada Semarang. Batas wilayah kelurahan Bangetayu Wetan sebelah Utara adalah Kelurahan Sembungharjo, sebelah timur Kelurahan Penggaron 
Lor, sebelah selatan Kelurahan Tlogomulyo dan sebelah barat adalah Kelurahan Bangetayu Kulon.

Berdasarkan hasil survey lapangan masyarakat RT 11 RW 02 Bangetayu Wetan sebagian besar tidak patuh memakai masker pada saat keluar rumah dan beranggapan bahwa new normal adalah kembali hidup normal seperti sebelum terjadi pandemic covid19. Masyarakat RT 11 RW 02 Bangetayu Wetan belum tahu tentang arti dari new normal atau adapatasi kebiasaan baru karena belum pernah mendapatkan pendidikan kesehatan tentang perilaku adaptasi kebiasaan baru. Oleh karena itu pemberian penyuluhan dan pelatihan tentang perilaku adaptasi kebiasaan baru di masa pandemi covid-19 akan sangat bermanfaat untuk meningkatkan pengetahuan dan mengembangkan perilaku sehat untuk mencegah penularan covid-19 khususnya di wilayah RT 11 RW 02 Bangetayu Wetan.

PKM ini dilaksanakan dengan tujuan untuk pengembangan pengetahuan masyarakat dalam meningkatkan kesehatan khususnya penerapan perilaku adaptasi kebiasaan baru di masa pandemi COVID-19. Adapun target dari kegiatan PKM ini adalah:

1. Masyarakat mampu memahami tentang adaptasi kebiasaan baru di masa pandemi COVID-19

2. Masyarakat mampu melakukan cara mencuci tangan dan memakai masker yang benar

3. Masyarakat mampu menerapkan perilaku adaptasi kebiasaan baru di masa pandemi COVID-19

\section{METODE}

Metode yang digunakan dalam kegiatan IbM ini adalah pendidikan kesehatan dengan menggunakan media PPT, video dan booklet. Kegiatan pendidikan kesehatan meliputi:

1. Pemberian pengetahuan tentang perilaku adaptasi kebiasaan baru di masa pandemic covid-19

2. Praktik tentang cara cuci tangan yang benar dan cara penggunaan masker yang benar
3. pendampingan dalam meningkatkan kemandirian melakukan perilaku adaptasi kebiasaan baru di masa pandemic covid-19.

Tahapan kegiatan PKM ini meliputi: survey tempat pelaksanaan kegiatan, mengurus perijinan dan administrasi kegiatan, serta persiapan materi dan media kegiatan. Setelah persiapan kegiatan selesai langkah selanjutnya yaitu pelaksananan kegiatan pendidikan kesehatan pada masyarakat RT $11 \mathrm{RW}$ 02 Bangetayu Wetan. Metode yang digunakan meliputi: ceramah, demonstrasi dan praktika. Adapun proses kegiatannya meliputi:

1. Melakukan pretest tentang materi yang akan diberikan yaitu adaptasi kebiasaan baru

Kegiatan ini berupa pebagian lembar kuesioner berisi pertanyaan tentang adaptasi kebiasaan baru

2. Melakukan penyuluhan kesehatan tentang adaptasi kebiasaan baru di masa pandemi covid19

Kegiatan ini berupa penyuluhan kesehatan pada masyarakat tentang adaptasi kebiasaan baru di masa pandemi covid-19. Dengan diberikannya penyuluhan tersebut diharapkan pengetahuan dan pemahaman masyarakat tentang adaptasi kebiasaan baru di masa pandemi covid-19 akan meningkat sehingga mampu menerapkan perilaku adaptasi kebiasaan baru untuk mencegah penularan covid-19.

3. Melakukan pelatihan cara mencuci tangan dan cara memakai masker yang benar

Kegiatan ini berupa demonstrasi dan praktika tentang cara mencuci tangan dan cara memakai masker. Dengan kegiatan tersebut diharapkan masyarakat mampu melakukan cuci tangan dan memakai masker dengan benar secara mandiri sehingga mampu mencegah terjadinya penularan covid-19.

4. Melakukan posttest tentang materi yang sudah diberikan yaitu adaptasi kebiasaan baru Kegiatan ini berupa pebagian lembar kuesioner yang sama dengan pretest berisi pertanyaan tentang adaptasi kebiasaan baru yang dilakukan 
satu bulan setelah kegiatan pendidikan kesehatan.

\section{HASIL DAN PEMBAHASAN}

Kegiatan PKM ini diikuti oleh 25 orang masyarakat RT 11 RW 02 Kelurahan Banget ayu Wetan
Kecamatan Genuk Kota Semarang. Adapun hasil dari kegiatan PKM ini yaitu adanya peningkatan pengetahuan pada masyarakat tentang adaptasi kebiasaan baru yang akan dijelaskan pada tabel berikut:

Tabel 1. Perbedaan pengetahuan sebelum dan sesudah diberikan pendidikan kesehatan tentang adaptasi kebiasaan baru $(\mathrm{N}=25)$ Mei 2020

\begin{tabular}{|c|c|c|}
\hline Pengetahuan & Sebelum & Sesudah \\
\hline Baik & $6(24 \%)$ & $22(88 \%)$ \\
\hline Cukup & $14(56 \%)$ & $3(12 \%)$ \\
\hline Kurang & $5(20 \%)$ & $0(0 \%)$ \\
\hline
\end{tabular}

Berdasarkan tabel 1 terlihat bahwa terjadi peningkatan pengetahuan setelah diberikan pendidikan kesehatan tentang adaptasi kebiasaan baru menggunakan media PPT, video dan booklet. Dari $24 \%$ masyarakat yang memiliki pengetahuan baik menjadi $88 \%$. Media dalam pendidikan kesehatan adalah komponen penting yang harus diperhatikan. Media sangat menentukan keberhasilan pendidikan kesehatan oleh karena itu gunakan media yang tepat dan menarik sesuai dengan kebutuhan masyarakat (Bensley, 2008).

Tabel 2. Perbedaan perilaku sebelum dan sesudah diberikan pendidikan kesehatan tentang adaptasi kebiasaan baru $(\mathrm{N}=25)$ Mei 2020

\begin{tabular}{|c|c|c|}
\hline Perilaku & Sebelum & Sesudah \\
\hline Baik & $5(20 \%)$ & $14(56 \%)$ \\
\hline Cukup & $10(40 \%)$ & $6(24 \%)$ \\
\hline Kurang & $10(40 \%)$ & $5(20 \%)$ \\
\hline
\end{tabular}

Berdasarkan tabel 2 terlihat bahwa terjadi peningkatan perilaku setelah diberikan pendidikan kesehatan tentang adaptasi kebiasaan baru menggunakan media PPT, video dan booklet. Dari 20 $\%$ masyarakat yang memiliki perilaku baik menjadi 56 $\%$. Peningkatan yang perilaku penerapan adaptasi kebiasaan baru masyarakat belum maksimal karena masyarakat beranggapan wilayahnya masih aman dari COVID-19.

Pendidikan kesehatan merupakan proses meningkatkan kemampuan masyarakat dalam memelihara dan meningkatkan kesehatannya, untuk mencapai derajat kesehatan yang sempurna, baik fisik, mental dan social (Bensley, 2008). Pendidikan kesehatan yang diberikan pada masyarakat RT 11 RW 02 Kelurahan Bangetayu Wetan mampu meningkatkan pengetahuan tentang adapatasi kebiasaan baru.
Pengetahuan masyarakat tentang adapatasi kebiasaan baru penting dalam upaya pencegahan penularan penyaki tersebut. Karena tingkat pengetahuan sangat erat hubungannya dengan perilaku penerapan adaptasi kebiasaan baru seharihari (Notoatmojo, 2003). Apabila semua masyarakat menerapkan perilaku adapatsi kebiasaan baru maka akan meminimalkan penularan COVID-19. Hal tersebut sejalan dengan hasil penelitian Herdiana tahun 2020 tentang "Penanggulangan COVID-19 Tingkat Lokal Melalui Kebijakan Adaptasi Kebiasaan Baru (AKB) di Provinsi Jawa Barat". Hasil penelitiannya menunjukkan bahwa Kebijakan AKB secara substansi merupakan adopsi dari pedoman penyelenggaraan tatanan normal dari Badan Kesehatan Dunia (WHO) dan Pemerintah, isu yang muncul secara empiris yaitu sejauhmana penerapan kebijakan AKB mampu meminimalisir penyebaran 
COVID-19 yang sejalan dengan penyelenggaraan aktivitas masyarakat (Herdiana, 2020).

Penelitian yang dilakukan oleh Fajarani tahun 2020 yang berjudul "Pendampingan RT Siaga COVID-19 Melalui Sosialisasi dan Edukasi Adaptasi Kebiasaan Baru" juga menyatakan bahwa terjadi peningkatan pengetahuan masyarakat tentang protocol kesehatan dan adaptasi kebiasaan baru Kelurahan Sungai Bangkong. (Fajarani et.al., 2020). Hasil penelitian Satria tahun 2020 dengan judul "Penyuluhan Adaptasi Tatanan Kebiasaan Baru Desa Tangguh COVID-19" menyatakan masyarakat mulai memahami konsep tatanan kebiasaan baru dengan tetap menerapkan protokol kesehatan COVID-19, terutama trilogi pencegahan COVID-19 mulai dari menggunakan masker, jaga jarak dan sering cuci tangan dengan air bersih yang mengalir (Satria et.al., 2020)

Peneitian lain yang terkait dengan hasil PKM ini adalah penelitian Kusuma tahun 2020 dengan judul "Penguatan Pengetahuan Kader Posbindu-Ptm Rajawali Desa Sumbertebu Di Masa Adaptasi Kebiasaan Baru Pandemi COVID-19 menyatakan kegiatan penguatan pengetahuan kader PosbinduPRM Rajawali Desa Sumbertebu di masa adaptasi kebiasaan baru pandemi COVID-19 mampu meningkatkan pengetahuan dan keterampilan kader untuk melaksanakan Posbindu-PTM (Kusuma. et.al., 2020).

\section{SIMPULAN}

Tingkat pengetahuan masyarakat RT 11 RW 02 Bangetayu Wetan tentang adaptasi kebiasaan baru di masa pandemi COVID-19 meningkat sehingga mampu merubah perilaku masyarakat untuk menerapkan perilaku adaptasi kebiasaan baru di masa pandemi COVID-19 setiap hari khususnya memakai masker saat keluar rumah dan mencuci tangan. Akan tetapi perubahan perilaku tersebut belum optimal oleh karena masyarakat beranggapan wilayahnya masih aman dari COVID-19.

Perlu adanya tindak lanjut serta motivasi dari kader dan tokoh masyarakat setempat untuk selalu menerapkan perilkau adaptasi kebiasaan baru agar tidak terjadi penyebaran penularan COVID-10 di RT 11 RW 02 Bangetayu Wetan Kecamatan Genuk Kota Semarang.

\section{REFERENSI}

Bensley, Robert J dan Jodi B-F. (2008). Metode Pendidikan Kesehatan Masyarakat. Alih bahasa Apriningsih et.al. Edisi 2. Jakarta: EGC.

Fajarani, Tia. et.al. (2020). Penyuluhan Adaptasi Tatanan Kebiasaan Baru Desa Tangguh COVID-19. International Journal of Community Service Learning. Volume 4 Nomor 4, halaman: 290-296.

Herdiana, Dian. (2020). Penanggulangan COVID-19 Tingkat Lokal Melalui Kebijakan Adaptasi Kebiasaan Baru (AKB) di Provinsi Jawa Barat. Journal of Governance Innovation Volume 2, Number 2, halaman: 131-156.

Irawati, Theresia. (2020). Menuju Adaptasi Kebiasaan Baru. Menuju Adaptasi Kebiasaan Baru (kemkes.go.id)

Kemkes. (2020). Pandemi Covid-19 Tuntut Masyarakat Hidup Normal yang Baru. Kementerian Kesehatan Republik Indonesia (kemkes.go.id)

Kemkes. (2020). Ketahui: Adaptasi Kebiasaan Baru. Ketahui: Adaptasi Kebiasaan Baru - Apa yang Harus Kamu Ketahui? Covid19.go.id

Kusuma, Hadi YL. et.al. (2020). Penguatan Pengetahuan Kader Posbindu-Ptm Rajawali Desa Sumbertebu Di Masa Adaptasi Kebiasaan Baru Pandemi COVID-19. Jurnal Abdimakes Vol 1 No 1 halaman: 22-31.

Notoadmodjo, S. (2003). Pendidikan dan Perilaku Kesehatan. Jakarta: Rieneka Cipta

Satria, BA.et.al. (2020). Penyuluhan Adaptasi Tatanan Kebiasaan Baru Desa Tangguh COVID-19. Jurnal Pengabdian Masyarakat anoa. Volume 1, nomor 3, halaman: 107-122. 